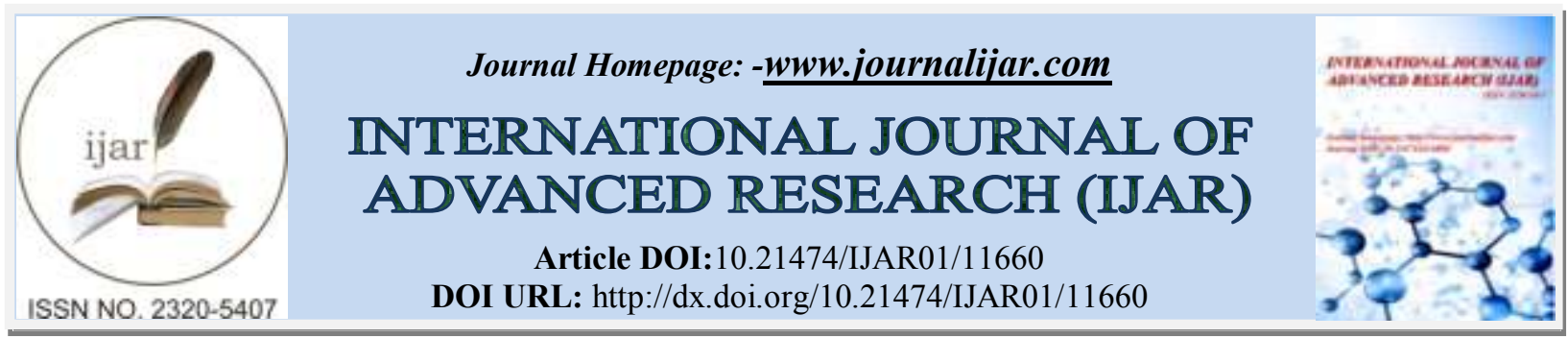

RESEARCH ARTICLE

\title{
PHYTOCHEMICAL SCREENING AND STUDY OF ANTIBACTERIAL ACTIVITY OF ROASTED AND UNROASTED SOAKED WHITE LUPINUS ALBUS SEED GROWS IN AWI ZONE, ETHIOPIA
}

Addisu Tamir and Sisay Awoke

Department of Chemistry, College of Natural Science, Wollo University, Ethiopia.

\section{Manuscript Info}

Manuscript History

Final Accepted: 14 August 2020

Published: September 2020

Key words:-

Lupin, Roast, Maceration, Extraction,

Antibacterial, Phytochemicals
Received: 10 July 2020

\begin{abstract}
Roasted soaked white Lupin albus $L$. seeds are popularly edible in Ethiopia. White Lupinis one of a garden plant cultivated by farmers in Western part of Ethiopia, west Gojam, Awi zone and traditionally used as snack food and for the treatment of hypertension. The current study aimed to evaluate phytochemical constituents and antibacterial properties of the Ethiopian lupin seeds i.e in case of roasted and unroasted soaked white Lupinusalbus L. seed which grows in Ethiopia, $452 \mathrm{~km}$ from Addis Ababa to north direction. The study was performed by purchased white Lupines albus seed samples which cultivated in, Awi Zone area, west Gojam, Ethiopia farmers and determined constituents of Phytochemicals (chemical compounds) and biological activities by extraction of roasted and unroasted soaked white lupinusalbus L. seed.The study revealed that the methanolic extract of roasted lupin seeds have no significant antimicrobial activity against Gram-negative bacteria(E.coli)and Gram positive bacteria (Staphylococcus aureus and Enterococcus faecalis). But methanolic crud extract and solvent fractionated of unroasted lupin seeds have significant antimicrobial activity against Gram positive bacteria (Staphylococcus aureus and Enterococcus faecalis but notGramnegative bacteria (E.coli). The Phytochemical analysis ofunroasted lupinseedshowed a presence of some bioactive secondary compounds such asflavonoids, terpenes, antraquinons, alkaloids, tannins, phenols and saponinsand roasted lupin seedshowed a presence ofterpenes, tannins, phenols and saponins. Therefore, unroasted lupin seeds could be a good source for secondary bioactive compounds and antibiotic agents for medical applications.
\end{abstract}

Copy Right, IJAR, 2020,. All rights reserved.

\section{Introduction:-}

Phytochemicalsare chemical compounds produced by plants. The name comes from the Greek word phyton, meaning plant. Some phytochemicals have been used as poisons and others as traditional medicine ${ }^{[1,2]}$ Human gets most of their food from plants, such vegetarian food is not a source of nutrition only, but they are also a source of many bioactive compounds which promote health, improve immunity and help in curing diseases. Many edible plants show numerous bioactive properties ${ }^{[2,3,4]}$. Primary products of plants include carbohydrates, proteins and fats, whereas what is known as secondary products (Phytochemical compounds) represents the bioactive compounds.

Corresponding Author:- Addisu Tamir

Address:- Department of Chemistry, College of Natural Science, Wollo University, Ethiopia.

E-mail: addisutamir@yahoo.com 
Lupin is an ancient leguminous plant; it has been cultivated and used as food for human and cattle since around 2000 years ago ${ }^{[3,5]}$.

There are about 400 species of lupins (Genus: Lupinus), among them only a few of them have been extensively studied. Lupins are characterized by the ability to grow on poor agricultural lands. Lupine seeds are a valuable ancient legume which contains high amount of protein, dietary fiber, oil, minerals and different functional components ${ }^{[4,5,6]}$. Lupine seeds are employed as a protein source for animal and human nutrition in various parts of the world, not only for their nutritional value (high in protein, lipids and dietary fiber), but also their adaptability to marginal soils and climates. Lupine flour is added for its nutritive value (high protein efficiency ratio) and also to provide functional properties in bakery and pastry products, protein concentrates and other industrial products, as well as for the elaboration of lactose-free milk and yoghurt analogues $[6,7,8]$.

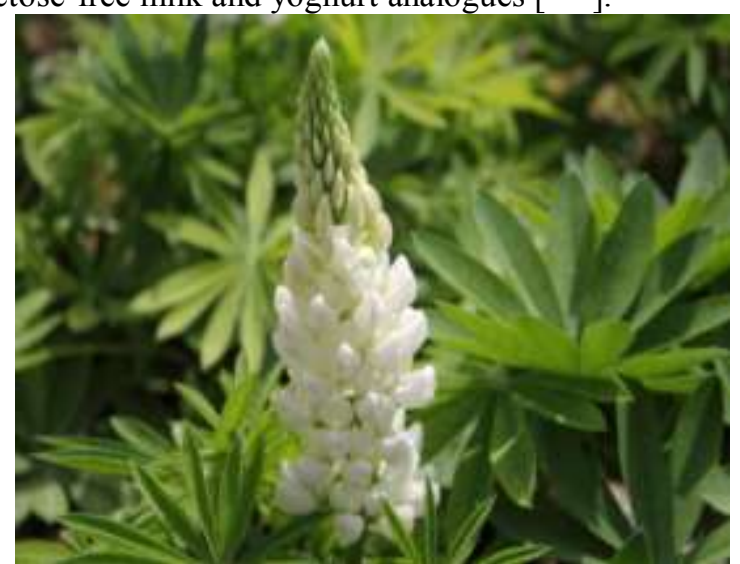

Fig. 1.:- Flower Photo taken by Addisu T. at Study area,Awi zone, Ethiopia.

Human consumption of lupine seeds has increased in recent years in many countries including Ethiopia ${ }^{[5,8,9]}$. Lupine seeds are used in traditional medicine in Africa and the Middle East as an anti-diabetic agent, and used topically to treat acne ${ }^{[8,9,10,11]}$.

The industrial shift of lupine seed utilization from feed to food has recently increased the scientific interest to explore its phytochemical composition and biological activities ${ }^{[9,12-15]}$. Lupine seeds contain significant amounts of polyphenols, carotenoids, phytosterols, tocopherols, alkaloids and peptides with antioxidant, antimicrobial, anticarcinogenic and anti-inflammatory activities. Among polyphenols, genistein and their derivatives (isoflavones) are of great importance because of their phytoestrogenic potential ${ }^{[12-15]}$. In Ethiopia Specially in west GojamAwi zone which is far from Addis Abeba $452 \mathrm{~km}$ to the north direction is people widely cultivated white Lupinusalbus $L$. Those people who cultivatedthe white Lupinusalbusutilized the seed of it as snack food and also they use traditionally for the treatment of hypertension in addition to use as a protein source for animal and also for the adaptability to marginal soils and climates. These people who cultivate white Lupinusalbus consumed seed as snack food after roasted and socked because of to remove bitter test but they used unroasted seed for the purpose of treatment of hypertension.

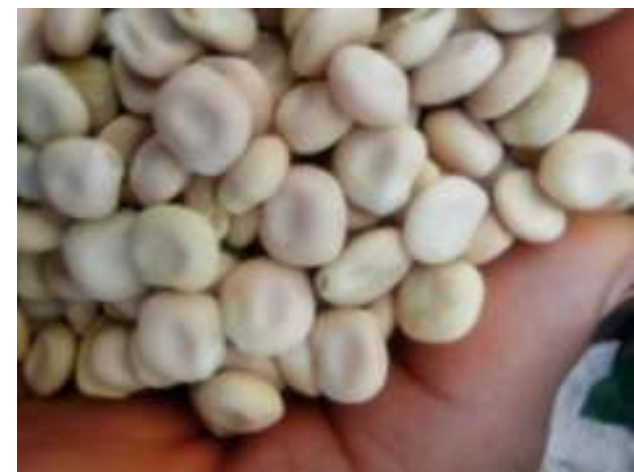

Fig. 2:- Photo seed taken by Addisu T.at study area, Awi zone, Ethiopia. 
According to Ethiopian central statistical agency, white Lupinusalbus L. is highly cultivated in Amhara region especially at Awi Zone, Ethiopia. In this area the roasted white Lupine seed is a popular snack food of residents. They prepare it firstly roast at metal pan and then macerated in running water for more than five days in order to get rid of the bitter taste and then salted, spiced and consumed as a snack food. But traditionally farmers are used unroasted white Lupine seed in the different parts of Ethiopia mainly in this study area for the purpose of hypertension treatment. The usage is depending on traditional knowledge without knowing of the difference between roasted and unroasted soaked chemical constituents and bioactivities properties of white Lupine seed. Means people used without the basis of scientific research unless having understanding of roasting and soaking for the purpose of removing bitterness.

Even if the content of proteins, carbohydrates and fats presence is tired to done by Paulos, G., 2009, there is no study on more chemical constituents and bioactivity properties in both roasted soaked and unroasted soaked white Lupinusalbus $L$. seed. In addition to this reason we were also inspired to know the presence or absence of effect of roasting on white Lupine seeds on the nature of chemical compound constituents which widely spread in high amount in the Awi zone, Ethiopia. Therefore; knowing the content of chemical compounds and bioactivity properties in roasted and unroasted white Lupin seed is a universal interest from a nutritional point of view.

\section{Materials and Methods}

\section{Study Area}

The study was conducted by purchasing dried white Lupinusalbus L. seed from west GojamAwi Zone, Ethiopia, especially from three Kebele, Gohena, Lideta and Gembeha farmers and then the dried Lupine seeds was purified from peels or unwanted materials.

\section{Materials}

The following apparatus were used in the experiment: rotary evaporator attached with vacuum pump (model, YC7124,China), electronic balance (1810-BAModel, China), grinder, water bath (Re201BL, Model Indian), Petri dish, micropipette (different size), thermometer, aluminum foil, cork-borer, measuring cylinder, Refrigerator (Samsung model RT34SUMG, Thailand), incubator (DHP-9052B Model), Separatory funnel, stand with clamps, stick swab, McFarland densitometer (Den-18 MC model), water distiller, sterilizer.

The chemicals and reagents that were used for this study are: methanol (99.9\%), n-hexane, chloroform, ethyl acetate, Muller Hinton Agar, 10\% iron chloride(II), distilled water, potassium iodide, Dimethyl sulphoxide (DMSO), concentrated sulphuric acid, hydrochloric acid, Iodine,10\% Ammonia, 5\% iron chloride, Ethanoic acid glacial, Wagner's reagent, normal slain solution, ciprofloxacin.

\section{Methodologies}

\section{Sample collection and processing}

The dried white Lupinusalbus L. seed sample was collected from three Kebeles, Gohena, Lideta and Gembeha farmers and then $500 \mathrm{~g}$ Lupine seeds was cleaned and roasted on a metal pan until changed it in to a brown color. This roasted seed was allowed to cool for about 15 minutes and it was soaked in running water in a clean jar and another unroasted 500g Lupine seeds was also soaked in a clean jar. In both case after the removed of bitterness, the seed was de-hull and the kernel allowed drying in open air. The air dried kernel seed was grinded by using blender machine

Each air-dried kernel Lupine seed powder $(500 \mathrm{~g})$ was macerated with methanol in clean dried round bottom flasks for seven days with occasional shaking at $25^{\circ} \mathrm{C}$. Thereafter the extract was filtered first with cotton wool followed by Whatman filter paper (hardened ash less circles $110 \mathrm{~mm}$ ) to obtain the crude extract solution. Theextracted solution was concentrated by rotary evaporator attached with vacuum pump (model, YC7124, China), at $45^{\circ} \mathrm{C}$ under reduced pressure. The concentrated crude extract was allowed to evaporate at room temperature in order to remove any remaining solvents and it was stored in a refrigerator at $4^{\circ} \mathrm{C}$ until next work.

\section{Fractionation}

The methanol crude extract (15.0 g) of both roasted and unroastedLupinusalbus L. seed was dissolved in100.0 mL of distilled water separately and fractionated sequentially in $100.0 \mathrm{~mL}$ of n-hexane, chloroform, and ethyl acetate. Each organic extract was dried with anhydrous sodium sulfate and concentrated under reduced pressure by using rotary evaporator. The phytochemical screening and antibacterial activity test were conducted for each of the fractions. 


\section{Phytochemical screening}

The methanol extract and solvent fractions were subjected to qualitative phytochemical screening to check for the presence or absence of different classes of secondary metabolites. Suitable reagents (as shown below) were used as confirmatory tests for various phytochemical components ${ }^{[12]}$.

Flavonoids (ferric chloride) test

The extract $(0.2 \mathrm{~g})$ was added to $1.0 \mathrm{~mL} 10 \% \mathrm{FeCl}_{3}$ and the mixture was shaken ${ }^{[12]}$.

Test for terpenes

Methanol extract $(0.2 \mathrm{~g})$ was mixed with $5.0 \mathrm{~mL} 1 \%$ hydrochloric acid and warmed for 30 minutes. 3 drop of concentrated sulfuric acid was then added and mixed well ${ }^{[12]}$.

\section{Test for anthraquinones}

The extract $(0.1 \mathrm{~g}$ in $3.0 \mathrm{~mL}$ methanol) was stirred for 5 minutes and then filtered. $1.0 \mathrm{~mL}$ of the filtrate was added to $1.0 \mathrm{~mL}$ chloroform and shaken thoroughly. The chloroform layer was taken off and. $2.5 \mathrm{~mL}$ of distilled water was added to it. The mixture was shaken with $2.5 \mathrm{~mL}$ dilute ammonia solution $(10 \%)^{[12]}$.

\section{Test for alkaloids (Wagner's reagent)}

Methanol extract $(0.2 \mathrm{~g})$ was treated with 5 drops of Wagner's reagent $(1.27 \mathrm{~g}$ of iodine and $2.0 \mathrm{~g}$ of potassium iodide in $100.0 \mathrm{~mL}$ of water) ${ }^{[12]}$.

\section{Test for Tannins}

About $0.5 \mathrm{~g}$ of the crude methanol extract was stirred with $10.0 \mathrm{~mL}$ of distilled water and filtered. To this solution 5 drops of iron chloride reagent was added to the filtrate ${ }^{[12]}$.

\section{Test for Phenols (Ferric chloride test)}

Methanol extract $(0.2 \mathrm{~g})$ was treated with aqueous $5 \%$ ferric chloride ${ }^{[12]}$.

\section{Test for Quinones}

Methanol extract $(0.2 \mathrm{~g})$ was treated with concentrated hydrochloric acid ${ }^{[12]}$.

\section{Test for Saponin (Foam test)}

Methanol extract $(0.2 \mathrm{~g})$ was dissolved in $6.0 \mathrm{~mL}$ of distilled water in a test tube. The mixture was shaken vigorously [12].

Test for Oxalate

Three drops of ethanoic acid was added to $0.3 \mathrm{~g}$ of methanol extracts ${ }^{[12]}$.

Table 1:-Phyto chemical screening test.

\begin{tabular}{|l|l|}
\hline Phytochemical test & Colour indication \\
\hline Flavonoids & woodly brownish pricipitate \\
\hline Terpenes & red colour \\
\hline Antraquinons & red colour in the ammonia upper phase \\
\hline Alkaloids & redish brown pricipitate \\
\hline Tannins & blue black pricipitate \\
\hline Phenols & deep blue \\
\hline Quinnons & yellow pricipitate \\
\hline Saponins & persistent foam \\
\hline Oxalates & Greenish black \\
\hline
\end{tabular}

A. In-Vitro Antibacterial Activity Test of the methanol extract and solvent fractions

In this study, the antimicrobial activity of methanol extract and solvent fractions were tested against selected bacteria. The standard American Type Cell Culture (ATCC) bacterial species of Escherichia coli (ATCC 25922) (gram negative) and Staphylococcus aureus (ATCC 25923), and Enterococcus faecalis (gram positive) were obtained from Amhara national regional state health bureu, Dessie regional health research laboratory, Ethiopia. The standard antibacterial disc used for the study was ciprofloxacin $5 \mu \mathrm{g} / \mathrm{well}$ for positive control and DMSO (100.0 $\mu \mathrm{L} /$ well) for negative control. 


\section{Media preparation}

Muller-Hinton agar powder $(19.0 \mathrm{~g})$ was added into $500.0 \mathrm{~mL}$ of distilled water in a flat-bottom conical flask. The mixture was heated with frequent agitation and boiled for one minute to completely dissolve the media. The flask was then tightly closed using cotton wool and further covered with aluminum foil. The mixture was autoclaved for 15 minutes at 121 degree Celsius after which it was left to cool down to room temperature. The media was poured in the Petri dishes in a laminar flow to give uniform depth of $4 \mathrm{~mm}$. The Petri dishes containing the media were then placed in sterile plastic bags and stored at a temperature of 6 degree Celsius before used $\mathrm{d}^{[1,16,17,18]}$.

\section{Determination of zone of inhibition}

The antibacterial activities of plant extracts were tested using agar well diffusion method ${ }^{[17]}$.About $70.0 \mathrm{~mL}$ freshly prepared sterile Mueller Hinton Agar (MHA) media was poured into $150.0 \mathrm{~mm}$ diameter agar plate and allowed to cool to room temperature. Within 15 minutes of adjusting the turbidity of the inoculums suspension to 0.5 McFarland standard, a sterile cotton swab was dipped in to adjusted microbial suspension, rotated gently and pressed firmly on the inside wall of the tube above the fluid level to remove excess inoculums from the swab. The swab was streaked to the entire surface of the MHA plate three times by rotating approximately $60^{\circ}$ each time to ensure even distribution of the inoculums. Petri-plates were left for $5 \mathrm{~min}$. at room temperatureandthen an equal distance hole with a diameter of $6.0 \mathrm{~mm}$ was punched aseptically using sterile cork borer tip. The extracts $(0.5 \mathrm{~g})$ of each were dissolved in $1.0 \mathrm{~mL}$ DMSO to give $0.5 \mathrm{~g} / \mathrm{mL}$ stock solution. Different concentrations of the extracts $(500-$ $10000 \mu \mathrm{g} / \mathrm{mL}$ ) were prepared by diluting the stock solutions in DMSO. DMSO and Ciprofloxacin were used as negative and positive control, respectively. Fixed volume $(100.0 \mu \mathrm{L})$ of the extracts and the controls were introduced into the labeled wells ${ }^{[20,21]}$. After placement of the plant extracts and controls into labeled wells, the plates were left undisturbed at room temperature for $2 \mathrm{~h}$. The plates were then incubated at $37^{\circ} \mathrm{C}$ for $24 \mathrm{~h}$. The Petriplate was then incubated at $30^{\circ} \mathrm{C}$ for a period of $48 \mathrm{~h}^{[21,22]}$. The complete zone of inhibition was measured in millimeter as judged by the naked eye using ruler. All tests were performed in triplicate for each bacterial species. The mean zone of inhibition and standard error of the mean (Mean \pm SEM) are calculated for the methanol extract and solvent fractions as well as for standard antibacterial.

\section{Result and Discussion:-}

In the preparation of crude methanol extracts from the dried roasted and unroasted soaked Lupinusalbus L. seed and solvent fractionations of methanol extracts, different percent yields were obtained. Among the solvents used for fractionating the methanol crude extracts, chloroform gave the highest and n-hexane has the lowest percent yields in both cases as shown in Table 2. The percentage yield of the crude extract was calculated using the following equation:

$\%$ yield $=\frac{\text { weightof thecrudeextract }}{\text { weightoftheinitialsample }} \times 100$

Similarly, the percentage yield of the solvent fraction was calculated using the following equation:

$\%$ yield $=\frac{\text { weightofthefractionatedextract }}{\text { weightofthemethanolextractused }} \times 100$

Table 2:- percent yield of roasted and unroasted soaked Lupinusalbus L. seed extracts.

\begin{tabular}{|c|c|c|c|}
\hline \multirow[b]{2}{*}{ S.No. } & \multirow[b]{2}{*}{ Types of extract } & \multicolumn{2}{|c|}{ Yield of extract In percent (\%) } \\
\hline & & roasted soakedLupinusalbus $L$. & unroasted soaked Lupinusalbus $L$. \\
\hline 1. & Crude methanol extract & 14.2 & 14.6 \\
\hline 2. & n-hexane fraction & 11.2 & 11.3 \\
\hline 3. & Chloroform fraction & 13.8 & 14.0 \\
\hline 4. & Ethyl acetate fraction & 12.4 & 12.7 \\
\hline
\end{tabular}

The percent yield difference of extracts of roasted and unroasted soaked Lupinusalbus L. seed was due to the nature of sample and solvent polarities used for the extraction.

\section{Phytochemical screening results of methanol extract and solvent fraction}

The preliminary phytochemical screening test results as shown in Table 3, one or more phytochemical components namely flavonoids, terpenes, antraquinons, alkaloids, tannins, phenols and saponins were detected in both the crude methanol extract and in solvent fractions in case of unroasted soaked Lupinusalbus L. seed whereas terpenes, tannins, phenols and saponins were detected in both the crude methanol extract and in solvent fractions of roasted soaked Lupinusalbus L. seed. But in both case of unroasted and roasted soaked Lupinusalbus L. seed, quinnons and oxalates were not observed in any of the extracts. In case of unroasted lupine seed the n-hexane fraction was 
observed to contain the minimum number of secondary metabolites i.e only antraquinons and Chloroform fraction contained four phytochemicals namely flavonoids, alkaloids, tannins and phenols. Ethyl acetate fraction resulted in three constituents, namely: terpens, alkaloids and phenols. All solvent fractions with the exception of $n$-hexane fraction were found to contain phenol. This in turn led us to conclude that phenol is fractionated by polar solvents. All fractionating solvents used during our study did not extract quinnons, saponins and oxalates. Among the fractionating solvents employed for the research, chloroform was better in fractionating secondary metabolites. Comparing the phytochemical constituent of the crude and the solvent fractionated showed that the crude contains more secondary metabolites than solvent fractionated. The difference in the phytochemical constituents of the fractionated solvents could be due to their polarity differences, with n-hexane being the least polar, chloroform having medium polarity and ethyl acetate being relatively the most polar. The results obtained in the study showed that the medium polar solvent (chloroform) contains more phytochemical constituents. Phytochemical constituents of the methanol extract and the fractionated extracts by the four solvents are summarized in Table 3.

Table 3:-Results of qualitative phytochemical Analysis of methanol crude extract and solvent fractionated roasted and unroasted soaked Lupinusalbus L. seed.

\begin{tabular}{|c|c|c|c|c|c|c|c|c|c|c|c|}
\hline \multirow{3}{*}{ S.No } & \multirow{3}{*}{$\begin{array}{l}\text { Phyto chemical } \\
\text { Constituents }\end{array}$} & \multirow{2}{*}{\multicolumn{2}{|c|}{$\begin{array}{c}\text { Crude } \\
\text { Methanol } \\
\text { Extracts }\end{array}$}} & \multicolumn{8}{|c|}{ Results of phytochemical screening } \\
\hline & & & & \multicolumn{2}{|c|}{$\begin{array}{l}\text { n-hexane } \\
\text { fraction }\end{array}$} & \multicolumn{2}{|c|}{$\begin{array}{l}\text { Chloroform } \\
\text { fraction }\end{array}$} & \multicolumn{2}{|c|}{$\begin{array}{c}\text { ethyl acetate } \\
\text { fraction }\end{array}$} & \multicolumn{2}{|c|}{$\begin{array}{c}\text { Fractionated of } \\
\text { n-butanol }\end{array}$} \\
\hline & & UR & $\mathrm{R}$ & UR & $\mathrm{R}$ & UR & $\mathrm{R}$ & UR & $\mathrm{R}$ & UR & $\mathrm{R}$ \\
\hline 1. & Flavonoids & + & - & - & - & + & - & + & - & + & - \\
\hline 2. & Terpenes & + & + & - & - & - & + & + & - & + & + \\
\hline 3. & Antraquinons & + & - & + & - & - & - & - & - & - & - \\
\hline 4. & Alkaloids & + & - & - & - & + & - & + & - & - & - \\
\hline 5. & Tannins & + & + & - & - & + & + & - & - & - & - \\
\hline 6. & Phenols & + & + & - & - & + & + & + & + & + & + \\
\hline 7. & Quinnons & - & - & - & - & - & - & - & - & - & - \\
\hline 8. & Saponins & + & + & - & + & - & - & - & - & + & + \\
\hline 9. & Oxalates & - & - & - & - & - & - & - & - & - & - \\
\hline
\end{tabular}

Observed $+=$ present, $-=$ absent

$\mathbf{U R}=$ unroasted, $\mathbf{R}=$ roasted

\section{Antibacterial susceptibility assay}

After the investigation of the phytochemical constituents, the crude methanol extract and the solvent fractionated extracts of roasted and unroasted Lupinusalbus $L$. seed were subjected to preliminary in-vitro antibacterial tests against gram positive and gram negative bacteria. The crude methanol extract and the solvent fractionated extracts of roastedLupinusalbus L. seed was not inhibits gram positive bacteria, S.aureusand E. faecalis at different concentration levels, $25 \mu \mathrm{g} / \mathrm{ml}, 50 \mu \mathrm{g} / \mathrm{ml}$, and $100 \mu \mathrm{g} / \mathrm{ml}$ and also gram negative bacteria at different concentrations. But unroasted Lupinusalbus L. seed of the crude methanol extract was effectively inhibits gram positive bacteria, S.aureusand E. faecalis at different concentration levels, $25 \mu \mathrm{g} / \mathrm{ml}, 50 \mu \mathrm{g} / \mathrm{ml}$, and $100 \mu \mathrm{g} / \mathrm{ml}$. But methanol crude extract of unroasted Lupinusalbus L. seed showed no any inhibition against gram negative bacteria, E.coli, when tested at the same concentration with that of gram positive bacteria. The bacterial activity of the crude methanol extract and solvent fractions have different zone of inhibition. This might be because of the difference in bacteria strain, phytochemical composition, types of solvent used etc. In this study, the crude methanol extract showed the highest inhibition zone against Staphylococcus aureus $(12.9 \pm 0.7 \mathrm{~mm})$ whereas chloroform fraction was the second with inhibition zone of $11.8 \pm 0.3 \mathrm{~mm}$ against Staphylococcus aureus. Methanol extract induced the zone of inhibition 11.6 \pm 0.9 against Enteroccocusfaecalis but did not show any activity against Escherichia coli. Among the solvent fractionated extracts, the chloroform fraction which was observed to contain alkaloids, flavonoids, phenol and tannins showed higher zone of inhibition (antibacterial activity). This might be due to the presence of more secondary metabolites in chloroform extract which are active to inhibition. But the n-hexane fractionated showed the least inhibition zone due to the presence of only one type of phytochemical, i.e. anthraquinones. The crude methanol extract and solvent fractionated did not show any inhibition at the concentration of $25 \mu \mathrm{g} / \mathrm{ml}$ because of lower concentration of the crude methanol extracted and solvent fraction extracted of the unroasted Lupinusalbus L. seed. The zones of inhibition for crude methanol extracted and solvent of n-hexane, chloroform and ethyl acetate extracted from unroasted Lupinusalbus L. seed summarized in Table 4, 5 and 6. The result clearly indicated inhibition against 
gram positive bacteria,staphylococcusaureus and Enteroccocusfaecalis, but both the crude extract and fractionations were not active against gram negative bacteria (Escherichia coli).

Table 4:-Antibacterial activities of crude methanol extract of unroasted soaked Lupinusalbus L. seed against gram positive bacteria (staphylococcus aureus).

\begin{tabular}{|c|c|c|c|c|c|c|}
\hline \multicolumn{2}{|c|}{ 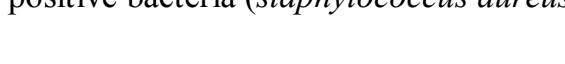 } & \multicolumn{5}{|c|}{ Zone of inhibition in diameter (mm) } \\
\hline Test bacteria & Solvents \& controls & $25 \mu \mathrm{g} / \mathrm{well}$ & $50 \mu \mathrm{g} /$ well & $100 \mu \mathrm{g} /$ well & $(+)$ control & (-) control \\
\hline \multirow{4}{*}{ S.aureus } & Crude methanol & NA & $7.9 \pm 0.05$ & $12.9 \pm 0.7$ & $21 \pm 0.0$ & NA \\
\hline & n-hexane & NA & NA & $8.1 \pm 0.4$ & $22 \pm 0.3$ & NA \\
\hline & Chloroform & NA & $8.4 \pm 0.2$ & $11.8 \pm 0.3$ & $21 \pm 0.4$ & NA \\
\hline & Ethyl acetate & NA & $7.3 \pm 0.1$ & $11.2 \pm 1.0$ & $20 \pm 0.0$ & NA \\
\hline
\end{tabular}

Values are expressed as mean \pm SEM $(\mathrm{n}=3)$. NA= no activity $(+)=$ positive control (Ciprofloxacin $(5.0 \mu \mathrm{g} / \mathrm{well})$ and $(-)$ control $=$ negative control $100 \mu \mathrm{L} /$ well (DMSO).

Table 5:-Antibacterial activities of crude methanol extracted and solvent fractionated of unroasted soaked Lupinusalbus $L$. seed against gram positive bacteria (Enterococcus faecalis).

\begin{tabular}{|c|c|c|c|c|c|c|}
\hline & & \multicolumn{5}{|c|}{ Zone of inhibition in diameter $(\mathrm{mm})$} \\
\hline Test bacteria & Solvents \& controls & $25 \mu \mathrm{g} / \mathrm{well}$ & $50 \mu \mathrm{g} /$ well & $100 \mu \mathrm{g} /$ well & $(+)$ control & (-) control \\
\hline \multirow{4}{*}{ E.faecalis } & Crude methanol & NA & $9.6 \pm 0.3$ & $11.6 \pm 0.9$ & $28 \pm 0.0$ & NA \\
\hline & n-hexane & NA & NA & $7.9 \pm 0.6$ & $28 \pm 0.0$ & NA \\
\hline & Chloroform & NA & $10.3 \pm 0.2$ & $11.5 \pm 0.3$ & $28 \pm 0.0$ & NA \\
\hline & Ethyl acetate & NA & $6.7 \pm 0.2$ & $10.3 \pm 0.7$ & $28 \pm 0.0$ & NA \\
\hline
\end{tabular}

Values are expressed as mean \pm SEM $(\mathrm{n}=3)$. NA= no activity $(+)=$ positive control (Ciprofloxacin $(5.0 \mu \mathrm{g} / \mathrm{well})$ and $(-)$ control $=$ negative control $100 \mu \mathrm{L} /$ well (DMSO).

Table 6:-Antibacterial activities of crude methanol extracted and solvent fractionated of unroasted soaked Lupinusalbus $L$. seed against gram negative bacteria (Escherichia coli)

\begin{tabular}{|l|l|c|c|c|c|c|}
\hline \multirow{2}{*}{ Test bacteria } & \multicolumn{5}{c|}{ Zone of inhibition diameter (mm) } \\
\hline \multirow{5}{*}{ E.coil } & Solvents & $25 \mu \mathrm{g} /$ well & $50 \mu \mathrm{g} / \mathrm{well}$ & $100 \mu \mathrm{g} / \mathrm{well}$ & $(+)$ control & $(-)$ control \\
\cline { 2 - 7 } & Crude methanol & NA & NA & NA & $29.8 \pm 0.0$ & NA \\
\cline { 2 - 8 } & n-hexane & NA & NA & NA & $29.8 \pm 0.0$ & NA \\
\cline { 2 - 8 } & Chloroform & NA & NA & NA & $29.8 \pm 0.0$ & NA \\
\cline { 2 - 8 } & Ethyl acetate & NA & NA & NA & $29.8 \pm 0.0$ & NA \\
\hline
\end{tabular}

Values are expressed as mean \pm SEM $(n=3) . N A=$ no activity $(+)=$ positive control (Ciprofloxacin $(5.0 \mu \mathrm{g} / \mathrm{well})$ and $(-)$ control $=$ negative control $100 \mu \mathrm{L} /$ well (DMSO).

\section{Conclusion:-}

The present study explored the phytochemical compounds from unroasted and roasted Lupinusalbus L. seed extract. In this work methanol was used as the main solvent to extract secondary metabolites and then further fractionation 
of the crude methanol extract was also done using different solvents based on their polarity, namely, n-hexane, chloroform and ethyl acetate. This study revealed that methanol extract of unroasted and roasted Lupinusalbus $L$. seed was gave us the highest percentage yield and n-hexane the least yield. Unroasted Lupinusalbus L. seed extract was contained variety of secondary metabolites; these were flavonoids, phenolics, tannins, saponins, alkaloids, antraquinons and terpenes whereas terpenes, tannins, phenols and saponins were screened from roasted Lupinusalbus $L$. seed extract. However, quinones and oxalates were absent in both roasted and unroasted Lupinusalbus $L$. seed extract. Due to the presence of wide variety of secondary metabolites, unroasted Lupinusalbus $L$. seed extract was showed superior in their antibacterial activities. Generally, the results of this study showed that methanol extract of the unroasted lupin was relatively more effective against the two gram positive bacterial strains, Staphylococcus aureus and Enteroccocusfaecalis, followed by the chloroform fraction. However, the methanol extracts and solvent fractions did not have inhibition activities against gram negative bacterial, Escherichia coli. But methanol extracts and solvent fractions of roasted Lupinusalbus $L$. seed extract did not have inhibition activities against gram negative bacterial, Escherichia coli and gram positive bacterial strains, Staphylococcus aureus and Enteroccocusfaecalis.

\section{References:-}

1. Emad,M., Kamal, A. , and Khalid, H.,(2017): Antimicrobial, antioxidant and phytochemical screening of lupin seeds. Journal of Microbiology, Vol.6 (1),1-8.

2. Mohammed,A., Elshazali, A.,Abuelgasim,A., Awad, R. and Elfadil, E., (2017): Effect of processing methods on alkaloids, phytate, Phenolics, antioxidants activity and minerals of newly developed lupin (lupinusalbus L.). Journal of Food Processing and Preservation, Vol.41, 45-49.

3. Walaa, I. ,Aniess, A.,andZenab, M.., (2015): Phenolic compounds and antioxidants capacity of sweet lupine derivatives-wheat Flour mixtures and the effects on diabetic rats.Journal of Environmental Science, Toxicology and Food Technology, Vol. 9, 61-69.

4. Hacer, L., and Nermin, B.,(2012): Evaluation of Physical, Chemical and Sensory Properties of Turkish Flat Breads (Bazlama and Yufka) Supplemented with Lupin, Buckwheat and oat flours.International Journal of Food Science and Nutrition Engineering, Vol. 2(5), 89-95.

5. Lei, L.(2009): phytochemical and pharmacological Perspectives of wheat grain and lupinSeed.Theses ,Publications@SCU.

6. Tizazu, H. And Shimelis, E., (2010): Chemical composition, physicochemical and functional properties of lupin (lupinusalbus) seeds grown in Ethiopia. African journal of food agriculture nutrition and development, Vol.10(8), 3-7.

7. Getachew, P., Umeta, M., Retta, N., Bekele,T., Molapisi, M. and Haki, G. , (2014): Fatty acid profile and mineral composition of traditionally processed gibto (Lupinusalbus) grown in Ethiopia.Bots. J. Agric. Appl. Sci. 10 .

8. Nermin, B. and Hacer, L., (2014): Utilization of lupin (lupinusalbusl.) flour and bran with xylanase enzyme in cookie production.Agricultural research communication centre, Vol. 37(3), 264-271.

9. Paulos, G., (2009): Chemical composition and the effects of traditional processing on nutritional composition of gibto (lupines albus. L), A thesis submitted to the School of Graduate studies of AAU in partial fulfillment of the requirement for the Degree of Master of Science in Food Science and Nutrition.

10. Mohamed, A. and Rayas.D., (2015): Composition of Lupinusalbus. Cereal Chem. Vol. 72(6), 643-647.

11. Prusinski, J.,(2017):WhiteLupin (LupinusalbusL.) Nutritional and Health Values in Human Nutrition.Czech J. Food Sci., Vol.35.

12. Mostafa, A., Awad, A. and Haiam,.E., (2013):Effect of Debittering Process on Characterization of Egyptian Lupine Seeds Oil (Lupinusalbus). Australian Journal of Basic and Applied Sciences, Vol. 7(2), 728-734.

13. Sweetingham M., Kingwell R., (2008): Lupins - reflections and future possibilities. In: Palta J.A., Berger J.D. (eds): Lupins for Health and Wealth. Proceedings of the 12th International Lupin Conference, Sept 14-18, 2008, Fremantle, Western Australia: 514-525.

14. Tizazu H., Emire S.A., (2010): Chemical composition, physicochemical and functional properties of lupin (Lupinusalbus) seeds grown in Ethiopia. African Journal of Food, Agriculture, Nutrition and Development, 10: 3029-3041.

15. Torterolo K., Planchuelo A.M., Ravelo A.C., (2011): Consumer uses, commercialization and counter prices of white lupins and other pulses in Cordoba, Argentina. Book of Abstracts of the 13th International Lupin Conference, June 6-10, 2011, Poznan, Poland, Workshops (5).

16. Tabrett, S. D. Blyth, N. Bourne, and B. Glencross.9, (2012): Digestibility of Lupinusalbuslupin mean in barramundi (Latescalcarifer). Aquaculture 364:1-5. 
17. Von Baer, E., I. von Baer, and R. Riegel., (2009): PecosaBaer: A new cultivar of white lupin with determined bushy growth habit, sweet grain and high protein content. Chilean J. Agri. Res.69:577-580.

18. Aniess WIM, Khalil AF and Mosa ZM., (2015). Phenolic compounds and antioxidants capacity of sweet lupine derivatives-wheat Flour mixtures and the effects on diabetic rats. IOSR Journal of Environmental Science, Toxicology and Food Technology 9(5) 61-69.

19. Elbbandy $M$ and Rho J-R (2014). New flavone-di-C-glycosides from the seeds of Egyptian lupin (Lupinustermis). Phytochemistry Letters 9 127-131. El

20. Shahhat IMA, Ghazal GM and Mohamed GS (2014). Effect of ascorbic acid and niacin on protein, oil fatty acids and antibacterial activity of Lupinustermis seeds. International Journal of Pharmacognosy and Phytochemical Research 6(4) 866-873

21. Dey, S.K.; Banerjee, D.; Chattapadhyay,S.; Karmak, K.B., (2010):.Antimicrobial activities of some medicinal plants of west Bengal. Int J Pharm Sci. 1, 1-9.

22. Kuta, F.A.; Tsado, D.J.; Garba, S.A.; Saidu, A.N., (2015): Antibacterial activity of the leaf and stem bark crude extracts of Khayasenegalensis. Med Aromat Plant Res J. 3, 9-15. 